\title{
Ice, water and sediments: a cold, wet and muddy account of a very fun life in science
}

\author{
Svante Björck (D)
}

Received: 20 February 2019/Accepted: 16 March 2019/Published online: 9 April 2019

(C) The Author(s) 2019

\section{A cold and wet start}

As a Quaternary geologist, it was a great honor, and surprise, to receive an IPA Lifetime Achievement Award. At the same time, it reminded me about my life-long fascination with water and what it can hold and produce, in terms of life, power, magnificence and spectacular end-products. As a young boy I had the dangerous hobby of jumping between ice flakes (in Swedish called "jumpa") on lakes and in the Baltic Sea bays of Stockholm (Fig. 1). Over and over again, my mother tried to prevent me from engaging in this exciting activity, with the punishment being to go to bed instead of eating dinner when I came home wet and cold (but happy). I can understand her consternation, when my answer, in spite of my hunger, always was the same: "It's really worth it Mum!" Otherwise, life was full of harmless water-related activities, such as building and draining dams in streams and brooks; and when the spring snow melted, I created many small canals on the road near our house.

The author was the recipient of a "Lifetime Achievement Award" presented by the International Paleolimnology Association in Stockholm, Sweden, on 20 June 2018.

\section{S. Björck $(\bowtie)$}

Department of Geology, Faculty of Science, Lund

University, Lund, Sweden

e-mail: svante.bjorck@geol.lu.se
These activities were always fascinating for me and are still a kind of "hobby," and even resulted in a short story (Björck 1991) in the Swedish literary magazine Ord och Bild. The theme of the story was based on fieldwork on Jameson Land in east Greenland in 1990. During the weeks in the field, we experienced nine full days of rain, which amounted to a whole year of normal precipitation in this fairly arid region. Our camp, consisting of Olafur Ingolfsson's, Mats Rundgren's and my own tent, plus a kitchen tent (Fig. 3), became completely flooded by water; permafrost prevented the water from infiltrating downward. I felt like I was in heaven! I started to canalize the standing water in the camp down to nearby Lake Boksehandsken (Boxing Glove!) in an intricate way, and with help from Olafur and Mats this resulted in a complex system of canals, which the helicopter pilots called "The Venice of Greenland." As long as the rain continued, our drainage system had to be maintained, and even my colleagues were caught up in this activity that prevented the tents from being totally flooded. This special experience resulted in the short story Vattentagen (in English, "Watertaken"). My 14-years-old daughter Åsa was very impressed that her father had published a real story and was convinced that we would now become rich! According to her, real authors, not researchers, earn loads of money!! 


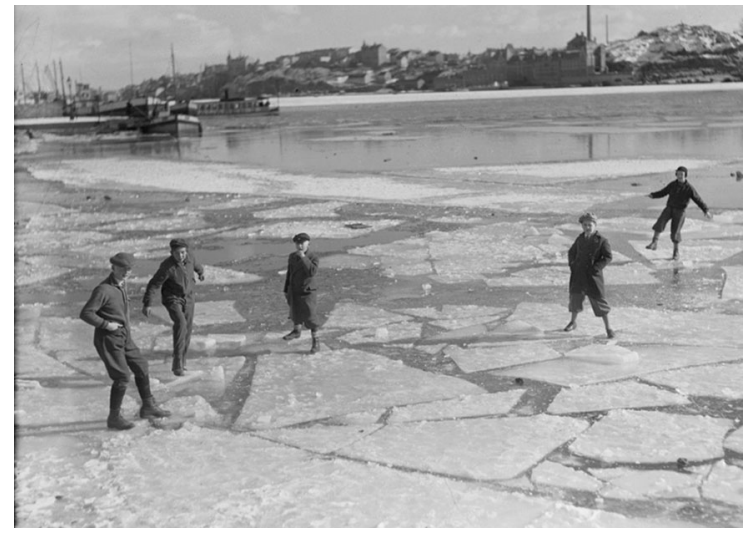

Fig. 1 Young boys jumping between ice flakes in Stockholm in 1930. From Aftonbladet and Stadsmuséet, photographer unknown

\section{0s: captivated}

When looking back at my career, the element of water has remained central, both during my education and in my research. After finishing high school in Malmö and studies in Mathematics and Geology at Lund University (LU), I spent a compulsory year in the Navy (once again water!). I moved to Gothenburg in the early 1970s for studies in Oceanography, mainly Physical Oceanography, which was a subject I greatly enjoyed. For a while I intended to become an oceanographer, and after 1 year of studies I planned for a Master's thesis. When I was then informed that one needs to own a boat or at least rent one to conduct field work for the Master's thesis, I became very disappointed, since this was beyond my student budget. I therefore decided to return to LU and study Limnology. By chance, I saw a recently published $\mathrm{PhD}$ thesis in Quaternary Geology, which dealt with the area around our family house in the province of Halland, between Göteborg and Lund. I had often stayed there a month or so during summers with cousins and second cousins, and had enjoyed the clear water of nearby spring-fed Lake Skärsjön, sailing and swimming. With excitement I read about the glacial landforms surrounding the lake and now redirected my plans towards Quaternary Geology.

After my Master's thesis in Quaternary Geology (1972), which focused on an ice margin delta in Halland, I worked with mapping for the Swedish Geological Survey (SGU) in Skåne, as well as hydrological work in South Halland, and I was offered an opportunity to undertake a $\mathrm{PhD}$. But doing what? My own idea was to work on a topic related to groundwater and geology, i.e. hydrogeology. As a young boy, I spent 3 years in India and Iran, and the memory of women carrying water buckets on their heads to their villages had never left me. Poor people need wells in their villages to live decent lives. Water is the most critical resource we have and I could perhaps make a difference? But once again, chance came into play. Björn Berglund and Erik Lagerlund had come up with a fascinating PhD topic: spatial and temporal relationships between raised deltas in the province of Blekinge and the shore displacement of the Baltic Ice Lake (BIL), the glacial lake that occupied the Baltic Basin until the onset of the Holocene. Would I be interested in such a project? As a "water person" this was very tempting; the impact of water from glacial rivers on the beautiful landscape of Blekinge, SE Sweden, and the lake level variations of the large BIL and its impact on the Blekinge shores, sounded extremely fascinating. Moreover, Blekinge is the province where I was born 25 years earlier! I could not resist their offer, especially in light of their enthusiasm for the topic.

I began my $\mathrm{PhD}$ studies in the mid-1970s by documenting the sedimentology and stratigraphy of numerous gravel pits in several of the river valleys of Blekinge. The other part of the field work was to reconstruct the shore displacement following deglaciation. To accomplish that, I needed to drill the oldest sediments in lakes situated at different altitudes below the highest shoreline, i.e. the shoreline that formed during or right after deglaciation, and estimate the age when the water bodies had become isolated from the BIL. Most of this work was carried out in winter from lake ice with Russian peat samplers or Livingstone piston corers, and in a few instances, we even cored from unstable, thin ice flakes. Although this was almost as exciting as the experiences of my youth, I found something even more exciting: the beauty and fascinating stratigraphy of late glacial lake sediments. Much of what I first saw, in terms of lithologic variability, was puzzling, and I was bewildered! Every lake had its own sedimentological character, and one never knew what to expect when daylight exposed the content of the corer; a new world of experiences opened up! Ever since those first drillings, I have been thrilled by the first sight of sediment cores from a new lake. 
My studies in gravel pits were mostly carried out in the beautiful summer landscape of Blekinge, often termed "the garden of Sweden," in stark contrast to the ice-cold lake drillings in winter. Since most of the raised deltas, and therefore also the gravel pits, are situated in river valleys, I was always close to running water and to river systems that once drained the retreating ice sheet. The deltas often contained rich information on the general lithostratigraphy of Blekinge, usually with stunning glacial varved clay (Fig. 6) as their lowest unit, a unit that was also often found in the bottom of the lake cores. With the aid of pollen analysis and ${ }^{14} \mathrm{C}$-dated lake sequences from different altitudes up to $70 \mathrm{~m}$ a.s.l., I planned to determine the age of the top-set beds in the different raised deltas of the BIL. Nevertheless, because the lakes that are today situated below the highest shoreline $(67 \mathrm{~m})$ were once bays in the glacial and barren BIL, and as a consequence of glacial unloading ended up as freshwater lakes, it was challenging to find "isolation indicators" other than diatoms. I finally, however, ended up with nine more-or-less good indicators, such as magnetic susceptibility, Pediastrum, loss-on-ignition, reworked pollen/spores.

I truly enjoyed life as a $\mathrm{PhD}$ student, both professionally and socially. I attended many good $\mathrm{PhD}$ courses, most of them at other Nordic universities, and became part of a network of Nordic PhD students. It was great to focus on a really fascinating topic, deepen my knowledge, and try to come up with new, though often half-baked ideas. Together with the lake drilling, the writing phase of my $\mathrm{PhD}$ work was the part that I most enjoyed. In my personal life, my greatest enjoyment was the birth of my lovely daughter $\AA$ sa in November 1977, for whom 12 years later, I named one of the lakes I cored in Antarctica. My thesis, which I defended in May 1979, was published as a monograph on the Quaternary lithostratigraphy and late glacial pollen stratigraphy of Blekinge. It included a shore displacement curve for the BIL and the hypothesis of a catastrophic drainage of the BIL at the Younger Dryas-Preboreal boundary. This drainage, which was on the order of $25 \mathrm{~m}$, had regional implications for the Baltic Sea Basin. The PhD thesis was later published in Fossils and Strata (Björck 1981).

During the last years of my $\mathrm{PhD}$ education, Björn Berglund and Gunnar Digerfeldt invited several foreign visitors, guests and post-docs to the department. They included, among others, Peter Beales, John Birks, Rick Battarbee and John Dearing, and many close friendships were formed. John Birks led a $\mathrm{PhD}$ course in multivariate statistics and I was flabbergasted. Peter Beales became a close friend and checked the English text of my thesis, and together with John Dearing, I published my 6th paper (Björck et al. 1982). One thing that astonished me was how young the English post-docs were! In Sweden it was very rare to be younger than 30 years old at the time of one's PhD defense. Immediately after I defended my $\mathrm{PhD}$ (Matti Saarnisto was a very friendly opponent), I worked for half a year for the province of Blekinge, documenting geologically interesting sites.

\section{0s: wider perspectives}

In the early 1980s I had a temporary, part-time position at the department with some teaching, but mostly research. Together with Gunnar Digerfeldt, who is my true paleolimnological role model, we decided to create late glacial sea level curves for southwestern Sweden. In contrast to Blekinge, this was a region that had experienced a glaciomarine deglaciation, and it was therefore easier to determine the isolation horizons with diatom analyses. Through comparisons between the Baltic Ice Lake development and the sea level development along the Swedish West Coast, we were able to better understand the dynamics of the late glacial development of the up-dammed Baltic Basin. During this very intense field work period, we cored many lakes, mainly from ice, and analyzed the sediments using geochemical variables, pollen and diatoms. The latter work was carried out by Hannelore Håkansson, an amazing diatom taxonomist. Over the years this resulted in six Björck and Digerfeldt papers. The field work ventures with Gunnar are still very special memories: walking through deep snow with our sled, drilling through meter-thick ice, coring to the bottom of the lake sediments, discovering and describing new, unseen sediment sequences, drinking strong hot coffee and smoking our pipes, and ending up trying to convince hotel personnel that the cores had to stay indoors to prevent them from freezing. And I learned a lot from Gunnar about drilling techniques and how to describe sediments, but perhaps most of all, about coming up with and testing "half-crazy" ideas based on what we 
saw in the cores; it was certainly the perfect "lakesediment-school"!

In June 1979 Herb Wright Jr. came to visit Björn and was given my thesis as evening literature! "What a bore," I thought, but a few days later Herb approached me and asked if I would be interested in joining his group in Minnesota, as a post-doc. He (and Björn) had the idea that I should apply to the Swedish Natural Science Research Council (NFR) for a guest researcher scholarship, a newly started NFR program. Since I both liked and was impressed by Herb, and I had never visited the U.S., I accepted the idea, wrote an application and was granted a 1-year scholarship in late 1980.

In the spring of 1981 I came to the Twin Cities with my small family and was well taken care of from the beginning. We lived in Dinky Town, close to the campus and to the Department of Geology and Geophysics, where Herb's Limnological Research Center (LRC) was located. There, a new network of friends and colleagues was established, some of whom I still meet more or less regularly-Sheri Fritz (and husband Joe Holmquist), Daniel Engstrom, Jim Almendinger, and Paul Glaser, and others who I first met at the LRC in 1981 or during later visits, often after workshops, field work or as guests in Sweden. They included Joe Shapiro, John Kingston, Geoff Seltzer, David R. Foster, Dora Barlaz, Eric Grimm, John Almendinger, Barbara Hansen, Ed Swain, Henry Lamb, Linda Shane, Bob Bright, George King, John King, George Jacobson, Margaret Davis, Ed Cushing, Tom Johnson, Joan Lennon, Jan Janssens and Cathy Whitlock. Herb's idea of a creative LRC environment included inviting young researchers and senior colleagues, usually from Europe, for long or short time periods. This provided the opportunity to meet Bill Watts, Roel Janssen, John Birks and Jan Lundqvist at the LRC, but also Rick Battarbee (and his wife Gill), who came to the LRC as a post-doc during my stay (Fig. 2), and with whom I shared a powerful 1974 Buick Skylark. From a social perspective, the LRC provided a great environment. We had many squash matches and watched ice hockey, American football and baseball games, and attended numerous unforgettable parties. Scientifically, my task was to "follow" the receding Laurentide Ice Sheet in NW Ontario by coring four lakes along a 450-km-long SW-NE transect. The aim was to reconstruct the pattern and age of the deglaciation, the Lake Agassiz

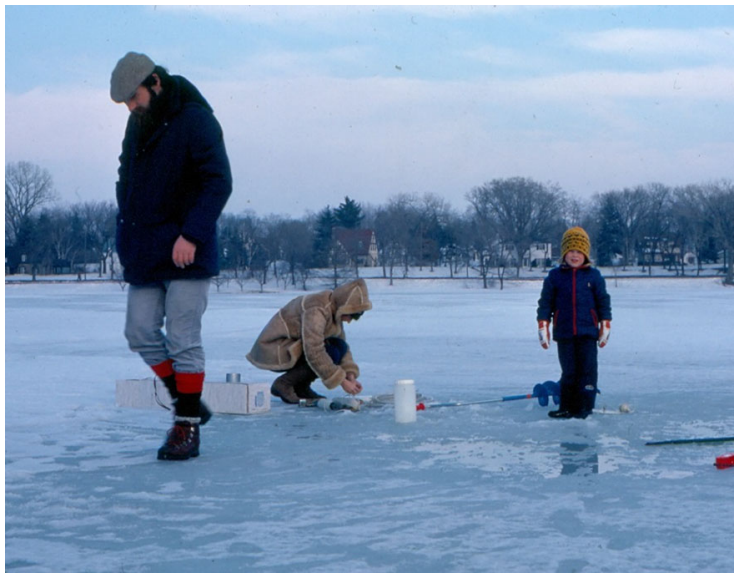

Fig. 2 Rick and Gill Battarbee with Åsa Björck on Twin Cities lake ice

sedimentation environment, Late Wisconsin-Middle Holocene vegetation immigration and dynamics, and related climate changes. Herb and I set off into the wilderness with the "banana-van" full of coring gear. It definitely was a memorable adventure to carry out field work with him, as I noted in my obituary of Herb (Björck 2016). Field work went perfectly (though many had warned me about the dangers of doing field work with Herb), and we collected many beautiful lake cores, including varved clays of Lake Agassiz. Herb's eagerness to find new sites and see the sediments in new cores was comparable to Gunnar's, and had also become my own obsession.

Most of my time at the LRC was devoted to analysis of the sediment lithology of the four selected lakes and their pollen and plant macrofossil assemblages. I spent the first few months learning many new pollen types, but after a while, counting became much easier because coniferous pollen grains were abundant and dominant. Most of the pollen work was carried out at the LRC, but some of the work also continued in Lund, after we moved back in May 1982. The study, which was published in 1985 (Björck 1985), inferred a long phase of park-tundra in the south, in contrast to a very short tundra period during the Holocene deglaciation farther north. It also highlighted the complex spread of white pine and alder and the peak influx of prairie pollen during the mid-Holocene spread of white pine. The distinct change in sediment composition and the disappearance of ash and elm pollen during the Younger Dryas caused much discussion; a Younger Dryas cooling in the U.S. was hardly accepted at that 
time, and I heard colleagues saying "it's only Europeans who find a Younger Dryas here." I was therefore not allowed to mention "Younger Dryas" in the published article, but "suggested cool period" was fine. A few years later it became more accepted that this cooling impacted at least parts of North America, especially along the east coast, but also further inland in the U.S., e.g. in Ohio as was shown by Linda Shane (Shane 1987) from the LRC.

During my stay at the LRC I applied for a research position at Lund University, which I got and started in the summer of 1982. Several times, however, I went back to the LRC, and carried out my own field work in the Giant's Range Area in northern Minnesota in 1984 (Fig. 3). Together with Gunnar Digerfeldt and Jim Almendinger, I worked in Parkers Prairie, westernmost Minnesota in 1986, where we cored prairie lakes in ice-cold conditions $\left(-20\right.$ to $\left.-30{ }^{\circ} \mathrm{C}\right)$. Whereas the former study was focused on local, Late Glacial vegetation and hydroclimate development, the latter was a Digerfeldt-type paleohydrological study, for which Gunnar would become rather famous (Digerfeldt 1988; Digerfeldt et al. 1992). Apart from the extremely cold field work conditions-cores froze to ice within a few minutes in the open windy air if we did not wrap them up immediately - the 1986 trip was "memorable" in a very different way. We had left Sweden 36 h after Swedish Prime minister Olof Palme had been murdered, departing a country that was in a deep shock. It was one of the few times when I did not feel like doing field work.

Back home I focused on my sea level collaboration with Gunnar and also on chronological issues related to deglaciation dynamics (Björck and Möller 1987),

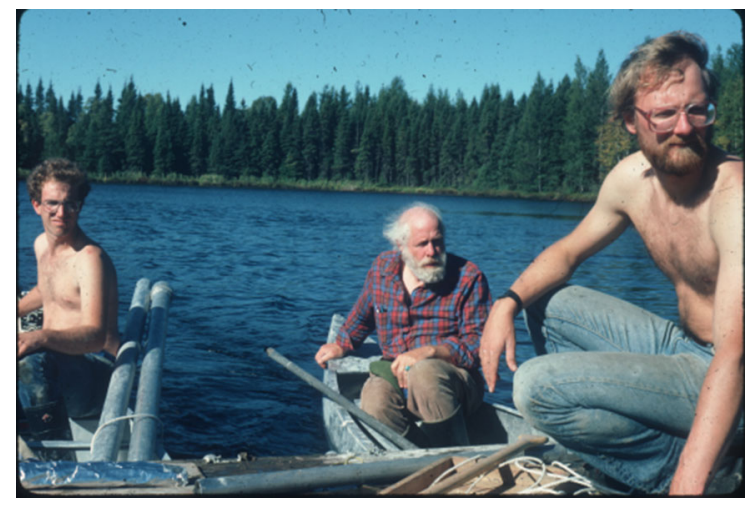

Fig. 3 Field work transport in N Minnesota with Geoff Seltzer, Herb Wright and George King
Baltic Sea development and paleomagnetism (Björck et al. 1987) with Per Möller, Per Sandgren and Benneth Dennegård and some very talented $\mathrm{PhD}$ students such as Bodil Liedberg-Jönsson, Geoffrey Lemdahl and N-O Svensson. Much of our work focused on drilling unexplored lakes that contained the most beautiful sediments, but also less beautiful Baltic Sea sediments. It struck me, over and over again, how individual each lake is in terms of its sediments and stratigraphy. Some of the Swedish lake sediments were more similar to some of the North American sediments than to sediments in a neighboring lake. Each lake seemed to have its own history, just like a living organism, at least when it came to lithologic details. Although I had by then seen many lake sediment cores, it was still impossible to foresee what would emerge from the bottom of each new lake; the thrill of probably being the first person to ever see a sediment core from a lake, has followed me throughout my career.

\section{0s: new colleagues, new scientific problems, new areas, new cores, new adventures}

In the late 1980s I obtained a "higher research position" in Late Cenozoic paleoclimatology, financed by NFR. At around the same time, my colleagues Christian Hjort and Olafur Ingolfsson persuaded me to join the Swedish Antarctic SWEDARP expedition. I did not need much convincing, since my research fit well into one of the focus areas of the expedition: paleoclimate. Field work in Antarctica, mainly on islands around the Antarctic Peninsula, was a highlight in many respects: the amazing landscape, with its unique and charming fauna, hard field work days that ended with cozy tent-nights in the harsh Antarctic environment (Fig. 4). Our lakes were both scenic and really "muddy," and often produced unexpected mixtures of sediments, such as laminated organic clays and silts with moss gyttjas, that were inter-layered with beautiful tephras (Fig. 4). The stiffness of the sediments resulted in some memorable (but enjoyable) hardships on the specially designed Zodiac dinghy from which we cored. But we knew that the tough times we experienced were worthwhile, since what we were doing was clearly pioneering field work in the area. Our most comprehensive and truly multiproxy study (pollen/spores, diatoms, mosses and 

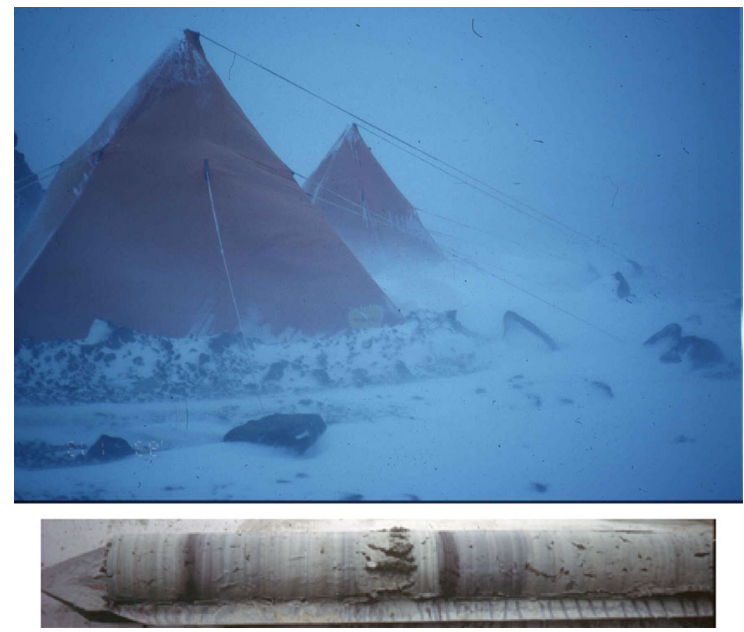

Fig. 4 Top, 5 days of snow storms on James Ross Island, Antarctica, and below, a core with tephras from Lake Åsa on the sub-Antarctic Livingston Island

geochemistry), was published in Journal of Paleolimnology (Björck et al. 1993). The paper described the hydroclimate history of the past 5000 years in the Graham Land region, mainly based on the sediments from Lake Asa. During that work I felt as much a paleolimnologist as a Quaternary geologist.

I spent most of the following years combining Antarctic work with studies in Sweden, Iceland and Greenland (Fig. 5), and also engaging myself in IGCP 253 (Termination of the Pleistocene) activities, where I met many future colleagues, and not least, my future

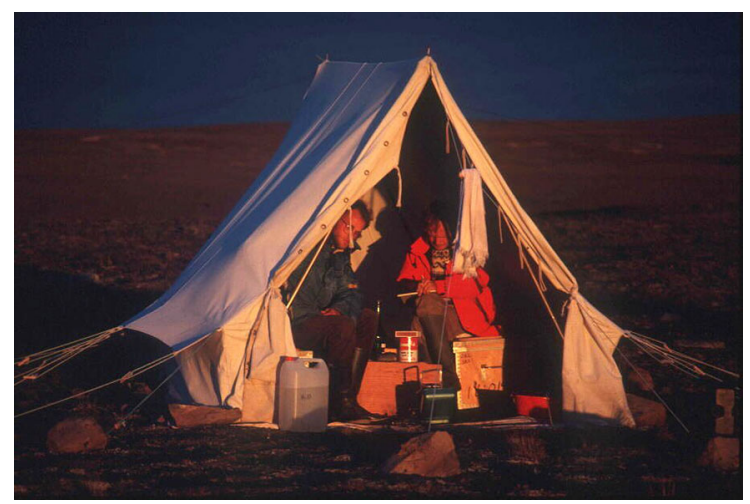

Fig. 5 Midnight sunset in our kitchen tent on Jameson Land, East Greenland, 1991, during the PONAM field work at Lake Boksehandsken. During 9 days of continuous rain we dug a sophisticated drainage system ("Venice of Greenland") to prevent the camp from being flooded. This tedious work resulted in a literary essay (Björck 1991). Mats Rundgren is on the left and I am on the right. Photo O. Ingolfsson wife Barbara Wohlfarth. One of the sub-topics of IGCP253 later became the starting point for the North Atlantic Seaboard Program (NASP), which was led by John Lowe and Mike Walker. John and Mike have since been two of my closest colleagues and friends with whom I have had numerous discussions on important topics in science, politics or football, often over a glass of beer.

In the early $90 \mathrm{~s}$ there was a big interest in chronological issues, especially concerning the reliability of different dating methods, such as ${ }^{14} \mathrm{C}$, U/Th and varved (clay) sediments. This often resulted in lively discussions at scientific meetings. The new AMS ${ }^{14} \mathrm{C}$ technique made it possible to ${ }^{14} \mathrm{C}$-date small plant remains, for example those found in annually laminated sediments (Fig. 6), but a big problem remained-calibration of pre-Holocene ${ }^{14} \mathrm{C}$ dates. Pre-Holocene calibration was very important, especially in light of the discovery that ${ }^{14} \mathrm{C}$ in the atmosphere had fluctuated considerably during the Late Glacial (Ammann and Lotter 1989). During her postdoc project, funded by the Swiss National Science Foundation, Barbara managed to ${ }^{14} \mathrm{C}$-date varved clays south of the Middle Swedish End moraine zone, i.e. older than the mid-Younger Dryas (Wohlfarth et al. 1995). Through Barbara's comprehensive work, it was later determined that the clay-varve-based Holocene part of the Swedish Time Scale was missing 700 ( \pm 300) years (Wohlfarth et al. 1997). These results were in line with estimates of the age difference between calendar years and the Swedish Time Scale at the end of the Younger Dryas (Björck et al. 1996; Andrén et al. 1999). This work brought us in contact with Bernd Kromer, a close friend and colleague ever since, whose deep knowledge of ${ }^{14} \mathrm{C}$ and calibration issues would become invaluable in my future work.

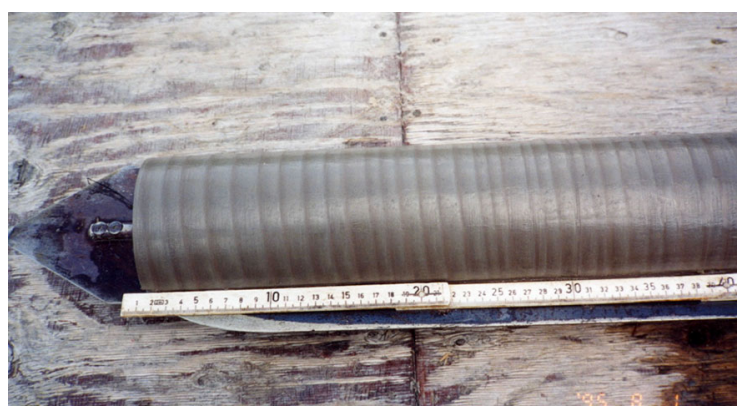

Fig. 6 Beautiful glacial varved clay from SE Sweden. Picture courtesy of Barbara Wohlfarth 
The NASP meeting/workshop in late spring 1993, which we organized in the archipelago of Blekinge (Fig. 5), was one of those memorable events, with intense discussions on Late Glacial climate and chronology, excursions to visit eskers and raised deltas and drill late glacial lake sites with spectacular varved clays (Fig. 6), and lively evening parties. Efforts to synchronize the North Atlantic Late Glacial climate-stratigraphy led to a 1994 issue in the Journal of Quaternary Sciences, which covered most of the European and NE American regions in separate manuscripts and included a summary paper (Lowe et al. 1994). Apart from our NASP leadership group, many of the younger and slightly older colleagues present at the Blekinge meeting (Fig. 7) would later become dedicated members of the successful INTIMATE group, which was initiated in 1995 by John Lowe and Mike Walker, and included, among others, Nalan Koc, Russel Coope, Bernd Kromer, Tomasz Goslar, Karen Luise Knudsen, Irka Hajdas, Sjoerd Bohncke, Wim Hoek and Stefan Wastegård. That workshop was also the last meeting that Bernd Becker, the German oak-pine dendrochronologist, attended before his untimely death.

For many years, I had been fascinated by the complex Baltic Sea history. The final drainage of $25 \mathrm{~m}$ from the large Baltic Ice Lake was eventually accepted when Bo Strömberg in 1991 found open pits with impressive boulder-pebble deposits, $7 \mathrm{~km}$ from Mt. Billingen. I was, however, frustrated by the fact that several eminent geologists had often focused their interest on only one, or in some cases two, of the 4-5 Baltic Sea stages, but without clarifying the puzzling transitions to tie the whole story together. A special

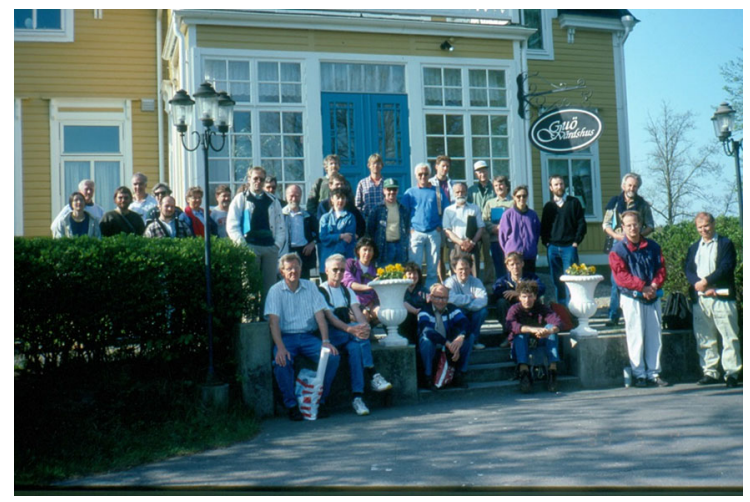

Fig. 7 The $\sim 40$ participants at the NASP 1993 meeting in front of the Guö Inn, SW Blekinge problem was the enigmatic Ancylus Lake stage, a key stage in the early Holocene, about which many different opinions existed. Given my interest in and research on sea level on the Swedish West coast and the Baltic Sea Basin, I was at a point where I felt prepared to explain some of the "mysteries" connected to the transitional phases. In 1993 I was invited by Thomas Andrén to present a keynote address at a Baltic Sea meeting on my thoughts about the Baltic Sea history. To my surprise, the response was very positive, at least from most of the attendants. The next task was to publish it, with maps and convincing facts. By creating a large number of shore-line diagrams, I estimated water levels around the Baltic coast for different time slices, with Barbara drawing the maps that would become so important (Björck 1995). This publication is one of the few of which I am proud because the main findings are still accepted, although some details have changed and new findings have been published over the years, e.g. a calendar-year-based chronology of the whole Baltic Sea history (Björck 2008; Andrén et al. 2011). The Baltic IODP 347 proposal, with Thomas Andrén and me as lead authors, resulted in the 2013 expedition that had six drill sites. Study of those cores will, in the near future, lead to many new insights about Baltic Sea history. One recent discovery, unrelated to IODP, comes from our submarine studies of a submerged landscape east of Skåne in southernmost Sweden, in collaboration with archaeologist Björn Nilsson. Numerous pine trees were found on the modern sea floor. By using a combination of ${ }^{14} \mathrm{C}$ dating and dendrochronology to date the death of the pine trees, our recently graduated $\mathrm{PhD}$ student Anton Hansson was able to determine the detailed course of the Ancylus Lake transgression. Anton showed that the pine trees had been flooded (and killed) by the Ancylus transgression, and established the timing of the transgression in great detail (Hansson et al. 2017). This was a dream I had harbored for more than 25 years and now it was accomplished, which felt great!

In 1994 I became the first Quaternary Geology professor in Copenhagen, Denmark, which was an honor, especially for a Swede! Denmark had fostered many pioneers in Quaternary geology, such as $\mathrm{K}$. Jessen, J. Troells-Smith, J. Iversen, and S. Th. Andersen, but it had never developed there into a full-fledged geological subject, as it had in Finland, Norway and Sweden, despite the fact that Denmark is 
totally covered by Quaternary deposits. There were several excellent colleagues in Copenhagen who worked on Quaternary issues, for example Michael Houmark-Nielsen (South Scandinavian glacial stratigraphy), Svend Funder and Ole Bennike (Quaternary of Greenland). Ole and I have cooperated ever since the mid-90s on many amazing projects. In terms of field work, we are both adventurous, which has resulted in many exciting findings, for example mild Younger Dryas summers in Greenland (Björck et al. 2002). For our field work, we used both a helicopter and a Zodiac dinghy to reach our coring sites. Many of the lake sequences we drilled in Greenland were spectacular, especially those with marine-lacustrine transitions in the archipelago of SW Greenland. These latter cores enabled us to present a sea level curve, led to a longstanding cooperation with our great colleague Kurt Lambeck, and generated a model of the SW Greenland ice sheet (Bennike et al. 2002). The years in Denmark also involved much field work, often with Master's students in different parts of Denmark, the Faroe Islands and Greenland. We were lucky that the few cold winters in Denmark made it possible to drill from lake ice, resulting in some exceptional Late Glacial and Holocene sediment sequences. When the scientific debate on the climate stability of the Last Interglacial (Eem) started in the mid-90s, an Eemian ancient lake sequence on Jutland, previously pollen analyzed by Svend Th. Andersen (Andersen 1965), caught my attention. We sampled the open lake section and together with colleagues at the Geological Institute, e.g. Michael Houmark-Nielsen and Nanna Noe-Nygaard, we analyzed a range of climate proxies. Our study (Björck et al. 2000) showed that this ancient lake had been influenced by fairly large hydroclimate changes, and that the Eemian in southern Scandinavia was perhaps more variable than the Holocene.

Another challenge was to date lake sediments from Lake Igelsjön in the Billingen area, with U/Th. These Holocene sediments are dominated by compact algal and carbonate gyttjas, and were some of Gunnar's and my favorite lake sediments, in terms of beauty. Parallel U/Th and ${ }^{14} \mathrm{C}$ dating, in collaboration with our postdoctoral researcher Carsten Israelsson and with Chris Hawkesworth, showed that this type of sediment could indeed be dated using U/Th (Israelson et al. 1997). It still surprises me that U/Th dating is not used more often for this specific sediment type. Another highlight from Lake Igelsjön was that Dan
Hammarlund, together with me and Danish colleagues, were the first to detect a clear climate response of the 8.2-ka event in a Swedish lake, using stable isotopes (Hammarlund et al. 2003).

Other highlights in the late 1990s were summer schools in Switzerland and Iceland for PhD students and post-docs, where I also met Gerard Bond and Raimund Muscheler. The vivid discussions with Gerard are memorable, and Raimund would, in the early 2000s, become a post-doc in Lund and later an important member of the Lund Quaternary group, ending up in 2015 as my successor as Head of Quaternary Science in Lund.

The enthusiasm of my 15 Danish Master's students was important for my well-being during the 6 years in Copenhagen. Sigfús Johnsen and his ice core group at the Niels Bohr institute also played a crucial role. Sigfús inspired my research in Copenhagen and during the subsequent years in Lund. I learned much from his open-mindedness in terms of scientific problem-solving, very similar to Gunnar Digerfeldt's approach. Sadly, he died in 2013, but his creativity, knowledge and generous and warm personality will remain in my memory forever.

In hindsight, the bipolar seesaw mechanism was possibly the most important and fascinating scientific finding for me during my career and would become crucial for my future research. It was formulated and later theoretically depicted by three giants in our field of science: Wally Broecker (Broecker 1998), Sigfús Johnsen and the youngster Thomas Stocker (Stocker and Johnsen 2003). With great celebrations, Wally received the Crafoord Prize from Queen Silvia in Lund in 2006. He died at the age of 87 on 18 February 2019. A true giant has left us.

\section{0s: new challenges}

In the late 1990s two of my most seminal papers were published (Björck et al. 1996, 1998). These were team works, partly inspired by Sigfús Johnsen, Bernd Kromer and the INTIMATE group, to synchronize ice cores, marine sediments and lake and terrestrial deposits. I had also applied for a professorship in Quaternary Geology at Lund University, which had become vacant after my former PhD supervisor Björn Berglund retired. When I was offered the position, I gladly accepted, partly because commuting between 
Lund and Copenhagen was tiring and time consuming (although, ironically, the Öresund Bridge opened the same day, July 1st 2000, I started in Lund!), and partly because of the strong multidisciplinarity of the Lund Quaternary group, with many $\mathrm{PhD}$ students, in contrast to Copenhagen. Björn had been a pioneer in modern paleoecology, but had also contributed tremendously to modern research education, so it was a great challenge to take over and lead.

The Greenland modeling and sea level work continued and was concluded superbly by my $\mathrm{PhD}$ student Charlotte Sparrenbom (Sparrenbom et al. 2006). All the PhD students I have supervised from the mid-90s into the early 2010s have succeeded extremely well within the university or the corporate world: Dan Hammarlund, stable isotopes and paleoclimate; Hui Jiang, diatoms and North Sea paleoceanography; Mats Rundgren, Icelandic sea level changes and vegetation history; Camilla S. Andresen, paleoclimate in North Iceland-South Greenland based on marine and lake sediments; Rixt de Jong, Holocene vegetation and wind history in SW Sweden; Karl Ljung, paleoclimate studies on Tristan da Cunha, and Johan Striberger, climate history of Lake Lögurinn, East Iceland. All of them had one thing in common: their often thrilling results were based on beautiful sediment cores that inspired their curiosity. I am also extremely happy to have had the opportunity to continue cooperating with my former graduate students after they graduated. Of my $>160$ publications after 1993, one or more of my (usually former) $\mathrm{PhD}$ or Master's students were 1st author or co-author on 75, i.e. $>45 \%$.

Over all these years, I had worked on many 'cold' Atlantic islands-on Greenland, Iceland, and the Faroe Islands in the north, and on Livingston Island, Elephant Island and James Ross Island in the subAntarctic. But during a visit to the Azores with Barbara in winter 2001, with all its lush, green islands and its many beautiful volcanic lakes (Fig. 8), I decided to create a paleoclimate island transect through the Atlantic. If successful, it would be an excellent test of the fascinating bipolar seesaw concept, by adding paleoclimatic and paleoenvironmental information from terrestrial/island sites. This was the starting point of my "Atlantis Project" (in hindsight an Atlantic equivalent to the continental PEPI-III, PoleEquator-Pole transects), which was funded by the Swedish Research Council (VR) for many years. Since

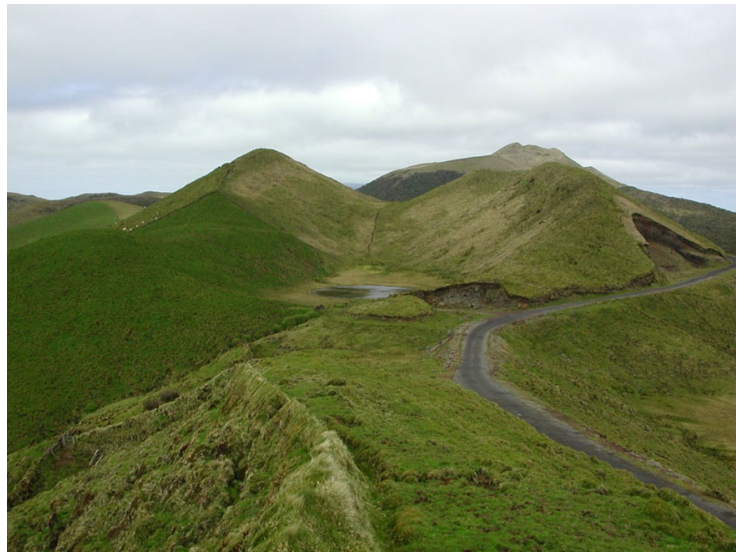

Fig. 8 Lake Caveiro, one of the many crater lakes drilled on the Azores. It is situated at $900 \mathrm{~m}$ a.s.l. on the island of Pico. With its 6000-years record (Björck et al. 2006), it is the oldest continuous lake record on the Azores. Portugal's highest mountain, Mt. Pico $(2350 \mathrm{~m})$, is hidden in the clouds in the background. Photo B. Kromer

the start of the Atlantis Project in 2002, I not only visited and worked on the Azores, but added many more exciting island lakes, bogs and wetlands to the transect. Target islands in the Northern Hemisphere were (and some still are) Jan Mayen, Greenland, Iceland, Faroe I, Pico, Terceira and San Miguel of the Azores, and Grenada in the Caribbean. In the Southern Hemisphere, I managed to work on the very remote islands of Tristan da Cunha and Nightingale in the Tristan da Cunha archipelago, on Isla de Los Estados to the east of Tierra del Fuego, on Isla Navarino to the north of Cape Horn and also on Ile Amsterdam in the Southern Indian Ocean. The volcanic island lakes usually contained highly variable lake sediment lithologies, which were sometimes strongly influenced by their setting, either as a result of being crater lakes, or from receiving continuous input of tephras. A fascinating example is the $30-\mathrm{km}$-long and $112-\mathrm{m}-$ deep Lake Lögurinn in Eastern Iceland, with its beautiful, annually laminated Holocene sediments. These record the dynamics of the surge history of the Eyjabakkajökull glacier (Striberger et al. 2011) and contain 157 tephra layers (Gudmundsdóttir et al. 2016).

Volcanic impact on these crater lakes has made it difficult, in some cases, to disentangle local from regional environmental signals. Craters are usually the only existing basins on volcanic islands, and as such they are often relatively young, and contain only 


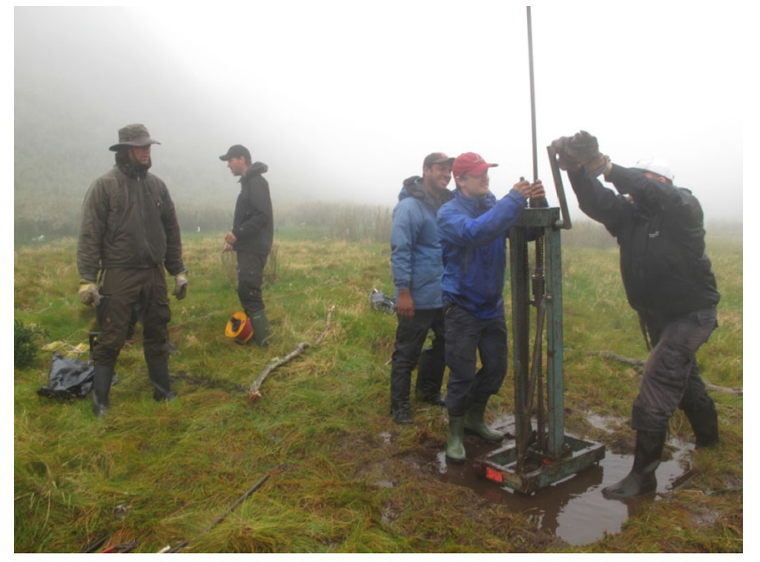

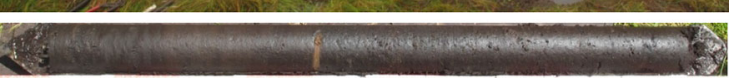

Fig. 9 Top, drilling on Nightingale Island with a Russian sampler connected to a chain-hoist, and below the unspectacular appearance of a 1-m core containing one of the most spectacular records from 1st Pond

Holocene sediments (except for the crater lakes on Grenada and Nightingale Island). This has been a drawback with respect to investigation of bipolar seesaw effects. Yet islands, where the terrestrial environment is influenced by atmospheric conditions and ocean dynamics, are unique, and by analyzing the sediments from so many lakes we have gained valuable new knowledge about how atmospheric changes influenced these oceanic settings. The 1st Pond record from Nightingale Island (Fig. 9) is probably the most spectacular one. It displays bipolar seesaw effects and shifting westerlies in the central South Atlantic during the last 36,000 years. Although the Last Termination record (Ljung et al. 2015) is published, we have during the last year struggled to compile the highly complex record of MIS3 and LGM. These island lake sediments may only record a relatively short history, as compared to adjacent marine cores. But their advantages include more reliable chronologies, higher sedimentation rates and atmospherically influenced proxies.

The paleoclimatic and paleoenvironmental data sets of the "Atlantis Project" would not have been possible to obtain without the engagement of many of my fantastic colleagues, post-docs, $\mathrm{PhD}$ and Master's students from 17 countries, e.g. Florian Adolphi, Yamoah Afrifa, Camilla S. Andresen, Paul Baker, Lena Barnekow, Ole Bennike, Anders Bjørk, Stein Bondevik, Daniel Conley, Anders Cronholm, Marilen

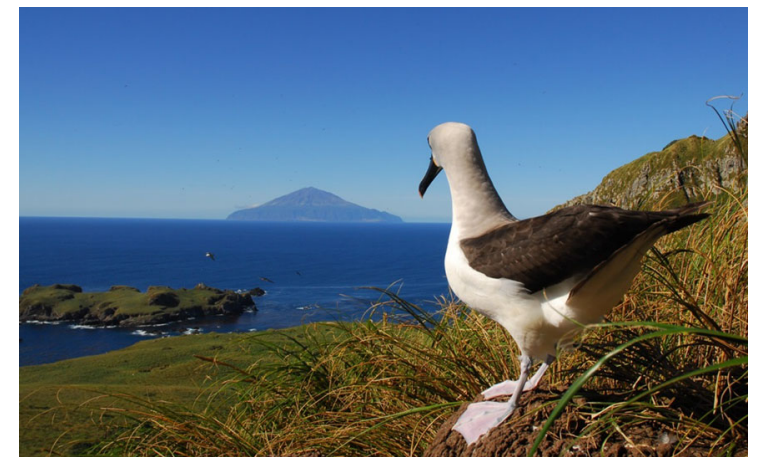

Fig. 10 Tristan da Cunha seen from Nightingale Island with a yellow-nosed Tristan albatross in the foreground. Photo A. Bjørk

Fernandez, Roger Flower, Sheri Fritz, Marianne Grauert, Charlotte Greve, James Haile, Ladislaw Hamerlik, Dan Hammarlund, Christian Hjort, Sofia Holmgren, Michael Houmark-Nielsen, Olafur Ingolfsson, Catherine Jessen, Hui Jiang, Masa Kageyama, Kurt Kjær, Bernd Kromer, Malin Kylander, Eiliv Larsen, Hanna Lindvall, Karl Ljung, Astrid Lyså, Elisabeth Michel, Raimund Muscheler, Per Möller, Jesper Olsen, Juan Federico Ponce, Charles Porter, Jorge Rabassa, Jayne Rattray, Hans Renssen, Tammy Rittenour, Peter Rosén, Mats Rundgren, Jesper Sjolte, Rienk Smittenberg, Ian Snowball, Thomas Stocker, Johan Striberger, Ingmar Unkel, Cinthia Uvo, Nathalie Van der Putten, Stefan Wastegård and of course Barbara Wohlfarth! Of these more than 50 co-workers, more than 25 joined me on one or more of the island expeditions and field work. The multidisciplinary character of this research also necessitated the involvement of many specialists.

The complex logistics of field work on far-away islands has meant that much time during the 2000s had to be spent on organization, but also on doing the field work and analyzing the spectacular sediments. I have often been asked where my favorite field work area is, but the answer to this question is tricky. Without doubt, the Antarctic settings are the most beautiful, especially if one includes the fascinating faunapenguins and other sea birds, seals and whales.

I must confess, however, that the desolate Tristan da Cunha archipelago $\left(37^{\circ} \mathrm{S}\right)$ is the most fascinating place I have visited (Fig. 10). It cannot be reached by plane (no landing strip), and is situated too far from Cape Town $(\sim 3000 \mathrm{~km})$ for a helicopter. Fishing vessels from Cape Town, to catch Tristan lobsters, 
arrive 5-8 times a year. Such a vessel transported us in 2003 to the main island Tristan da Cunha for our first field work, which lasted 1 month. All 275 inhabitants live in the capital Edinburgh of the Seven Seas, a small settlement in the northwest corner of the island. The island is totally dominated by the huge and high (2062 m a.s.l.) Queen Mary's Peak volcano. Our main target in 2003, however, was the small and uninhabited Nightingale Island, since Tristan da Cunha itself is too volcanically active to accommodate sediments older than the Late Holocene. Unfortunately, we were able to visit Nightingale Island for only 1 day, but were able, with the help of the islanders, to collect a complete Holocene sequence, which became part of Karl Ljung's thesis (Ljung and Björck 2007).

We definitely had to go back to Nightingale Island! In January 2010, after a long preparation, we set sails from the Falkland Islands with Charlie Porter's ketchrigged sailing boat Ocean Tramp. After 2 weeks of sailing with hard westerlies through the screaming 50s and roaring 40s, and with up to 15-m-high waves, we arrived at Nightingale Island and could begin our 2 weeks of field work. This island must be one of the most fascinating, but also remote, field work areas one can imagine. We stayed in huts made by the Tristan islanders for their annual visit to collect eggs, among colonies of 3 million pairs of great shearwaters, 125,000 pairs of rock-hopper penguins, 10,000 pairs of broad-billed pion and storm petrels, 5000 pairs of yellow-nosed albatrosses, thousands of fur seals, surrounded by a vast and never-ending roaring ocean with its fish and lobsters for evening barbecues. The unique memories from these weeks will never fade! The same goes for the memorable trip back to a "stable" continent. After a few days of sailing against the westerlies and towards the Falklands/Malvinas, it became obvious that such an undertaking was not feasible. We therefore sailed north to catch more favorable winds and after 33 days of sailing in highly variable weather, we ended up in Uruguay with our more than 50 sediment cores. The day we landed in Punta del Este, found a hotel, had our first shower in more than a month, and had a fantastic dinner with great Uruguayan wine, stands out as one of those extraordinary experiences. It is also an example of what I find so fascinating with what we as field-workdependent scientists have a chance to experience: the large contrasts between often very tough conditions in the field, cold-windy-wet-dirty, and the coziness and comradery in a kitchen tent, around a camp fire or a dinner table, after days or weeks of work. Contrasts like that, experienced with close colleagues, in combination with a good "harvest" of sediment cores, raises my life quality considerably. As geologists and paleolimnologists, we should continuously remind ourselves and our students about the very special opportunities our scientific field provides us.

Fieldwork-related experiences are very different from the administrative duties that we all need to carry out. I served as a member of the Earth Science Panel of the Swedish Research Council (VR) for many years and enjoyed it, mostly because of my general interest in research. When asked to run for (and later elected), I was happy to become a member (and later chair) of the Board for Natural and Technical Sciences at VR between 2007 and 2012. Those years gave me many new perspectives on science. General reflections from that time indicate that the best ways to maintain strong basic research are to strive for high quality among the members of different scientific panels; to convince politicians that basic research is the platform for all research; to prioritize individual, smaller, often more productive research projects; and to elect active university researchers to the boards of the grant funding research councils/foundations, as is done for example at VR, but with a restriction of a maximum service period, to avoid corruption, which may occur with long periods of power.

Apart from the Atlantis Project, I have worked with a variety of research topics during the last 15 years, in large part because of the research network I have become part of over the years. Some of it has been loosely associated with the Atlantis Project, such as the tough field work in 2014 in the huge peat-covered caldera of Ile Amsterdam in the Indian Ocean, and the hardships with drilling Jan Mayen's only lake in 2016. Other topics have been related to sea level changes in southernmost South America and Greenland, aeolian studies in Sweden and Tierra del Fuego, Eemian stratigraphy, paleoceanography in the China Sea with my former PhD student Hui Jiang (now a professor in Shanghai), the significance of solar forcing in paleoclimate research with Raimund Muscheler and his group, and of course my old favorite topics: Late Glacial climate (often with Barbara) and the Baltic Sea development. Regarding the latter, I have greatly enjoyed work with Martin Jakobsson on modeling the BIL drainage and finding fascinating evidence for a 
large earthquake fault in Lake Vättern at the Younger Dryas-Preboreal boundary, right after the BIL drainage (Jakobsson et al. 2014). I have also been lucky to have a wife, Barbara, who has done fieldwork for many years in Southeast Asia. I spent much time with her travelling around in Thailand, Laos and the Philippines, and visiting her at the highly renowned Nanyang Technical University in Singapore, with its famous Earth Observatory. But once again, fieldworkrelated activity was the most memorable part of my travels. The island of Ko Phra Thong in Southwest Thailand was heavily impacted by the 2004 tsunami. Kruawun Jankaew, then a researcher at Chulalongkorn University in Bangkok, found evidence for earlier tsunamis (Jankaew et al. 2008) in drained ditches on the island. Barbara and I were invited by her to be part of a field campaign during the 2012-2013 New Year, which included drillings, by hammering down the Russian sampler to find even older tsunami records. The sweaty, muddy work in ditches with water snakes (Fig. 11) was mixed with tropical nights with delicious Thai food and cold beers, and warm nights in straw huts, celebrating the New Year at the beach with a warm bath. A true contrast to the field work conditions in Antarctica or Greenland!

It has struck me that in spite of the many risks connected with the type of field work that Quaternary Geologists and Paleolimnologists often carry out far from civilization, very few serious accidents occur. From experience, we are aware of how to avoid the most obvious risks, and pass on this knowledge to junior scientists-but some are more safety-minded than others. Perhaps the most safety-minded person I

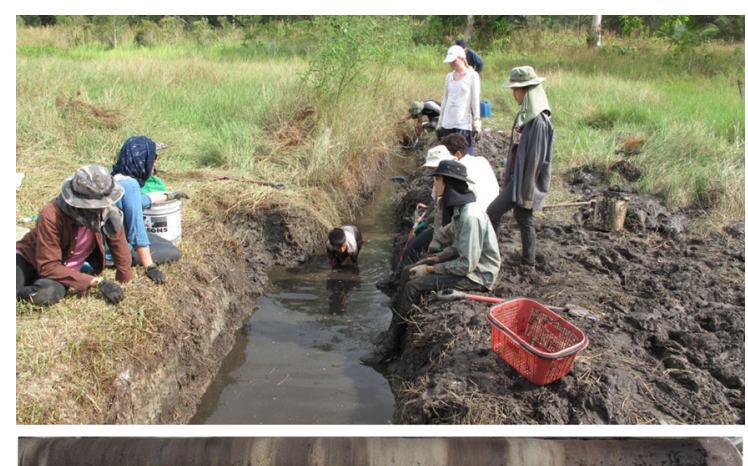

Fig. 11 Top, fieldwork in a trench on the island of Ko Phra Thong, southwest Thailand. Below is a $1-\mathrm{m}$ core showing the light silt-rich tsunami layers have worked with was Charlie Porter, a world-famous vertical wall climber, who probably survived decades of climbing because of his ability to evaluate risks. When his professional climbing career was over, he began sailing in southern South America, putting up weather stations and transporting Quaternary scientists into the fjords of Chile and to sub-Antarctic islands. In 2005 he and his 66-foot ketch-rigged sailing boat Ocean Tramp transported my party to the Argentinian island Isla de Los Estados (Staaten Island), east of Tierra del Fuego, for a combined expedition of glacial geology and lake sediment/peat drilling. We kept in close and regular contact thereafter, and during a visit to Maine in $2008 \mathrm{I}$ asked Charlie if he and his Ocean Tramp could transport us to Tristan da Cunha from the Falkland Islands. Charlie's response was "no problem, Svante!" And it was true-we had only minor problems that we handled well, in spite of being under the spell of the screaming 50 s and roaring 40 s for 45 days, and difficult landing conditions on Nightingale and Tristan da Cunha. Long nights together on the captain's bridge created a tight link between us and we decided to arrange another trip in 2011 to the beautiful Beagle Channel (BC), with all its glaciers (Fig. 12). This shorter expedition was supposed to be a reconnaissance trip for evaluating the possibility of finding submarine lake sediments in shallow lagoons, and thereby work out the local sea level history. We did find interesting sediments, and therefore planned for a full expedition with Ocean Tramp from Charlie's home port, Puerto Williams, north of Cape Horn, and into the $\mathrm{BC}$ archipelago, together with my colleagues and

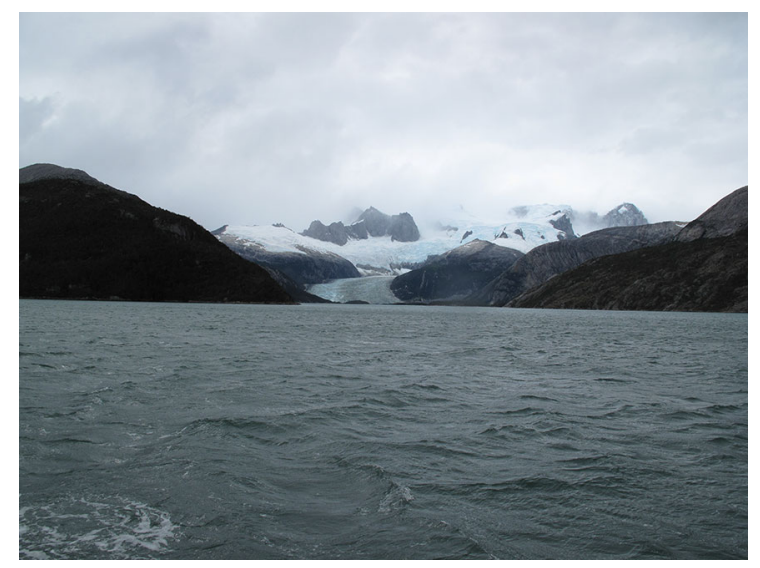

Fig. 12 The spectacular landscape of the Beagle Channel with its mountains and glaciers down to sea level 


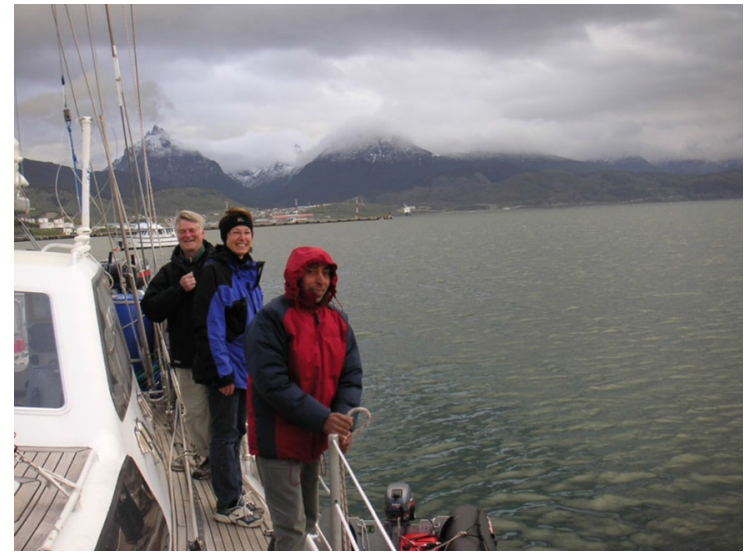

Fig. 13 Charlie Porter in the background, with Barbara and Juan in the front, onboard Charlie's ketch Ocean Tramp in the harbor of Ushuaia, southernmost Argentina

friends Per Möller and Per Sandgren. We left Sweden in March 2014, looking forward to some interesting fieldwork. During the intermediate landing in Madrid, however, I received a terrible message. Charlie had suddenly passed away in Punta Arenas from a massive heart attack after having been transported from Puerto Williams. I was in shock. My friend Charlie (Fig. 13), who always put safety first, had been struck by a risk that was impossible to assess. After careful deliberations, we decided to go on with our trip to Puerto Williams. We found a place to stay and were informed by locals that Charlie had told them that a guy named "Svante" could use his pickup truck if he showed up! So instead of sailing around with Ocean Tramp in the $\mathrm{BC}$, we drilled eight sites, lagoons/lakes/bogs, on the island of Isla Navarino. This study, which is now being wrapped up, is dedicated to Charlie. Charlie Porter was indeed a VERY special person and like Sigfús, who died the year before, will stay in my memory forever. Without Charlie, the many studies of the Atlantis Project would not have been possible.

In the above accounts, I described field work, sediment cores, $\mathrm{PhD}$ supervision and science, but another important component for my well-being has been to teach and stimulate undergraduate and graduate students. My teaching load has varied over the years, usually between 20 and $40 \%$, and it was never a burden, not even in Copenhagen where I often had more than 50\%. Instead, I have usually felt very good and "productive" after a few hours of teaching students about some of the exciting revelations that the geologic record holds, and making them realize that we usually have only a few pieces in a giant puzzle; the challenge is to add a few more pieces, and gradually create the larger picture, in spite of the fact that most pieces are still lacking. Although I have received nominations and prizes for my research accomplishments, I am most proud of the teaching prize I received from the Science Faculty students in Copenhagen in 1997, in spite of my strong Danish-Swedish accent!

It will be impossible to finish everything that I/we have started over the years, but some interesting studies will be concluded in the coming years, such as the Jan Mayen and Ile Amsterdam studies, the Beagle Channel sea level curve, and most importantly, the long sequence from Tristan da Cunha. After a few years of retirement, often missing teaching, I have learned that I feel best when I am writing and when I am doing field work. For the latter reason, I will launch a marine expedition in March 2019 from Punta Arenas (Bay of Magellan) to the Beagle Channel, together with Björn Nilsson, a submarine archaeologist, and two Chilean geo-archaeologists, Flavia Morello and Manuel San Roman. We will explore the fantastic archipelago of Southern Patagonia/Tierra del Fuego for drilling lagoons/lakes that can be used for further sea level studies, and we also hope to find early archaeological sites. With the aid of sedDNA, we might even be able to determine the presence of the earliest people at the "End of the World," (Fig. 14) and who they were. Something I look forward to, because having fun is possibly the most important

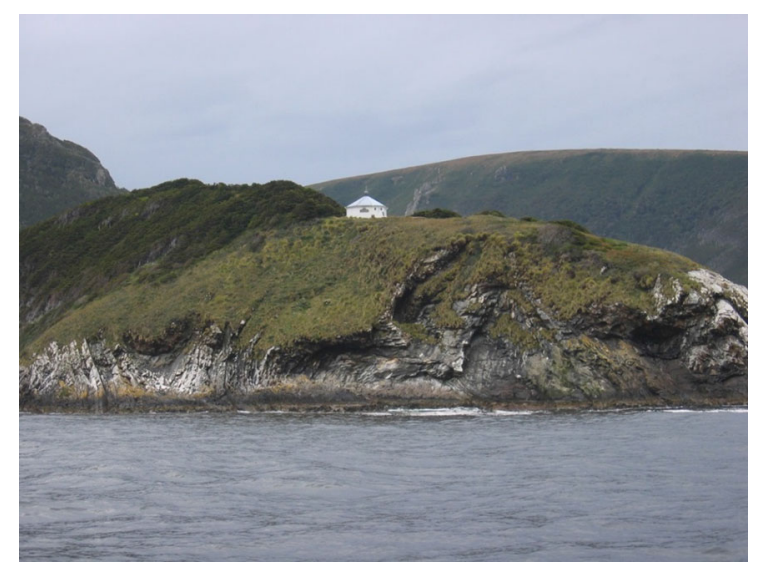

Fig. 14 This renovated lighthouse at the easternmost point of Isla de Los Estados gave the name to Jules Verne's novel "The Light-house at the End of the World" (Verne 1905). Our studies on this spectacular island have generated several papers, e.g. Björck et al. (2012) 
component in my work and research!!! THANK YOU EVERYONE I HAVE WORKED WITH OVER THE YEARS!! Without you there would not be a Quaternary Geologist/Paleolimnologist named Svante B. In conclusion: "No human is an island, entire of itself." (From John Donne's Devotions [1624]).

Open Access This article is distributed under the terms of the Creative Commons Attribution 4.0 International License (http:// creativecommons.org/licenses/by/4.0/), which permits unrestricted use, distribution, and reproduction in any medium, provided you give appropriate credit to the original author(s) and the source, provide a link to the Creative Commons license, and indicate if changes were made.

\section{References}

Ammann B, Lotter AF (1989) Late-glacial radiocarbon and palynostratigraphy on the Swiss Plateau. Boreas 18:109-126

Andersen ST (1965) Interglacialer og interstadialer i Danmarks kvartær. Meddelelser fra Dansk Geologisk Forening 15:486-506

Andrén T, Björck J, Johnsen S (1999) Correlation of Swedish varves with the Greenland (GRIP) oxygen isotope record. J Quat Sci 14:361-371

Andrén T, Björck S, Andrén E, Conley D, Zillén L, Anjar J (2011) The development of the Baltic Sea basin during the last 130 ka. In: Harff J, Björck S, Hooth P (eds) The Baltic Sea basin. Springer, Berlin, Heidelberg, pp 75-98

Bennike O, Björck S, Lambeck K (2002) Estimates of South Greenland late-glacial ice limits from a new relative sea level curve. Earth Planet Sci Lett 6125:171-186

Björck S (1981) A stratigraphic study of Late Weichselian deglaciation, shore displacement and vegetation history in south-eastern Sweden. Foss Strata 14:1-93

Björck S (1985) Deglaciation chronology and revegetation in northwestern Ontario. Can J Earth Sci 22:850-871

Björck S (1991) Vattentagen, vol 4. Ord \& Bild 100, Göteborg, pp 93-94

Björck S (1995) A review of the history of the Baltic Sea, 13.0-8.0 ka BP. Quat Int 27:19-40

Björck S (2008) The late quaternary development of the Baltic Sea basin. In: The BACC Author Team (ed) Assessment of climate change for the Baltic Sea basin. Springer, Berlin, Heidelberg, pp 398-407

Björck S (2016) Herbert E. Wright Jr., 1917-2015: personal memories of a giant in Quaternary Sciences. Boreas 45:377-379

Björck S, Möller P (1987) Late Weichselian environmental history in southeastern Sweden during the deglaciation of the Scandinavian Ice Sheet. Quat Res 28:1-37

Björck S, Dearing JA, Jonsson A (1982) Magnetic susceptibility of Late Weichselian deposits in southeastern Sweden. Boreas 11:99-111

Björck S, Sandgren P, Holmquist B (1987) A magnetostratigraphic comparison between ${ }^{14} \mathrm{C}$ years and varve years during the Late Weichselian, indicating significant differences between the time-scales. J Quat Sci 2:133-140

Björck S, Håkansson H, Olsson S, Barnekow L, Janssens J (1993) Palaeoclimatic studies in South Shetland Islands, Antarctica, based on numerous stratigraphic variables in lake sediments. J Paleolimnol 8:233-272

Björck S, Kromer B, Johnsen S, Bennike O, Hammarlund D, Lemdahl G, Possnert G, Rasmussen TL, Wohlfarth B, Hammer CU, Spurk M (1996) Synchronized terrestrialatmospheric deglacial records around the North Atlantic. Science 274:1155-1160

Björck S, Walker MJC, Cwynar L, Johnsen S, Knudsen K-L, Lowe JJ, Wohlfarth B, INTIMATE Members (1998) An event stratigraphy for the last termination in the North Atlantic region based on the Greenland ice-core record: a proposal by the INTIMATE group. J Quat Sci 13:283-292

Björck S, Noe-Nygaard N, Wolin J, Houmark-Nielsen M, Hansen HJ, Snowball I (2000) Eemian lake development, hydrology and climate-a multistratigraphic study of the Hollerup site in Denmark. Quat Sci Rev 19:509-536

Björck S, Bennike O, Rosén P, Andresen CS, Bohncke S, Kaas E, Conley D (2002) Anomalously mild Younger Dryas summer conditions in southern Greenland. Geology 30:427-430

Björck S, Rittenour T, Rosén P, França Z, Möller P, Snowball I, Wastegård S, Bennike $\mathrm{O}$, Kromer $\mathrm{B}$ (2006) A Holocene lacustrine record in the central North Atlantic: proxies for volcanic activity, short-term NAO mode variability and long-term precipitation changes. Quat Sci Rev 25:9-32

Björck S, Rundgren M, Ljung K, Unkel U, Wallin $\AA$ (2012) Multi-proxy analyses of a peat bog on Isla de los Estados, easternmost Tierra del Fuego: a unique record of the variable Southern Hemisphere Westerlies since the last deglaciation. Quat Sci Rev 42:1-14

Broecker WS (1998) Paleocean circulation during the last deglaciation: A bipolar seesaw? Paleoceanography 13:119-121

Digerfeldt G (1988) Reconstruction and regional correlation of Holocene lake-level fluctuations in Lake Bysjön, South Sweden. Boreas 17:165-182

Digerfeldt G, Almendinger JE, Björck S (1992) Reconstruction of past lake levels and their relation to groundwater hydrology in the Parkers Prairie sandplain, west-central Minnesota. Palaeogeogr Palaeoclimatol Palaeoecol 94:99-118

Gudmundsdóttir ER, Larsen G, Björck S, Ingólfsson O, Striberger J (2016) A new high-resolution Holocene tephra stratigraphy in eastern Iceland: Improving the Icelandic and North Atlantic tephrochronology. Quat Sci Rev 150:234-249

Hammarlund D, Björck S, Buchardt B, Israelson C, Thomsen CT (2003) Rapid hydrological changes during the Holocene revealed by stable isotope records of lacustrine carbonates from Lake Igelsjön, southern Sweden. Quat Sci Rev 22:353-370

Hansson A, Björck S, Heger K, Holmgren S, Linderson H, Magnell O, Nilsson B, Rundgren M, Sjöström A, Hammarlund D (2017) Shoreline displacement and human resource utilization in the southern Baltic Basin coastal zone during the early Holocene: new insights from a 
submerged Mesolithic landscape in south-eastern Sweden. Holocene. https://doi.org/10.1177/0959683617744262

Israelson C, Björck S, Hawkesworth CJ, Possnert G (1997) Direct U-Th dating of organic- and carbonate-rich lake sediments from southern Scandinavia. Earth Planet Sci Lett 153:251-263

Jakobsson M, Björck S, O’Regan M, Flodén T, Greenwood SL, Swärd H, Lif A, Ampel L, Koyi H, Skelton A (2014) Major earth-quake at the Pleistoce-Holocene boundary in Lake Vättern, Southern Sweden. Geology 42:379-382

Jankaew K, Atwater BF, Sawai Y, Choowong M, Charoentitirat T, Martin ME, Prendergast A (2008) Medieval forewarning of the 2004 Indian Ocean tsunami in Thailand. Nature 455:1228-1231

Ljung K, Björck S (2007) Holocene climate and vegetation dynamics on Nightingale Island, South Atlantic-An apparent interglacial bipolar seesaw in action? Quat Sci Rev 26:3150-3166

Ljung K, Holmgren S, Kylander M, Sjolte J, Van der Putten N, Kageyama M, Porter CT, Björck S (2015) The last termination in the central South Atlantic. Quat Sci Rev 123:193-214

Lowe JJ, Ammann B, Birks HH, Björck S, Coope GR, Cwynar L, De Beaulieu J-L, Mott RJ, Peteet DM, Walker MJC (1994) Climatic changes in areas adjacent to the North Atlantic during the last glacial-interglacial transition (14-9 ka BP): a Contribution to IGCP 253. J Quat Sci 9:185-198
Shane LCK (1987) Late-glacial vegetational and climatic history of the Allegheny Plateau and the till plains of Ohio and Indiana, U.S.A. Boreas 16:1-20

Sparrenbom CJ, Bennike O, Björck S, Lambeck K (2006) Relative sea level changes since 15,000 yrs BP in the Nanortalik area, southern Greenland. J Quat Sci 87:19-48

Stocker TF, Johnsen SJ (2003) A minimum thermodynamic model for the bipolar seesaw. Paleoceanography 18:000920

Striberger J, Björck S, Benediktsson ÍÖ, Snowball I, Uvo CB, Ingólfsson Ó, Kjær KH (2011) Climatic control of the surge periodicity of an Icelandic outlet glacier. J Quat Sci 26:561-565

Verne J (1905) Le Phare du bout du monde. Jules Hetzel

Wohlfarth B, Björck S, Possnert G (1995) The Swedish time scale: a potential calibration tool for the radiocarbon time scale during the Late Weichselian. Radiocarbon 37:347-359

Wohlfarth B, Björck S, Cato I, Possnert G (1997) A new middle Holocene varve diagram from the river Ångermanälven, northern Sweden: indications for a possible error in the Holocene varve chronology. Boreas 26:347-353

Publisher's Note Springer Nature remains neutral with regard to jurisdictional claims in published maps and institutional affiliations. 